\title{
Reported in Error
}

National Cancer Institute

\section{Source}

National Cancer Institute. Reported in Error. NCI Thesaurus. Code C160944.

A report was made erroneously. 